Journal of Finance and Banking Review

Journal homepage: www. gatrenterprise. com/GATRJournals/index. html

J. Fin. Bank. Review 4 (1) 01-07 (2019)

\title{
Firm Value, Firm Size and Income Smoothing
}

\author{
Arya Pradipta, Yulius Kurnia Susanto
}

Trisakti School of Management, Jl. Kyai Tapa No. 20, 11440, Jakarta, Indonesia

\begin{abstract}
Objective - Income smoothing is a form of earnings manipulation to show that the company's performance is good. Income smoothing can be detrimental to investors, because investors do not know the real financial position and fluctuations of the company. Management of the company engage in income smoothing because investors tend to focus only on the amount of profit reported without regard to the process of generating profits. The purpose of this research is to obtain empirical evidence about the effect of firm value and size on income smoothing.

Methodology/Technique - The sample of the research includes manufacturing companies listed on the Indonesian Stock Exchange from 2014-2016. The samples were determined using a purposive sampling method and there are 51 companies that meet the criteria used. This research uses a logistic regression method for data analysis.

Findings - The results of the research show that the effect of firm value on income smoothing is positive and significant. Meanwhile, the effect of firm size on income smoothing is negative and significant. Companies that create value in the eyes of investors will try to retain their investors by engaging in income smoothing. Income smoothing will convince investors to invest in the company. Meanwhile, large companies that are convinced that investors will continue to invest do not typically engage in income smoothing.

Novelty -This study proves that, in the context of agency theory, the principal's desires are not often aligned with the wishes of management which can give rise to agency costs, one of which occurs as a result of income smoothing. Further, firm size can minimize opportunist income smoothing actions.
\end{abstract}

Type of Paper: Empirical.

JEL Classification: G32, M41, M49.

Keywords: Income Smoothing; Firm Value; Firm Size; Agency Theory.

\section{Introduction}

Accounting information related to company performance is one of the useful factors in the decision making process for investors or shareholders. One source of accounting information is a company's financial statements (Gantino, 2015).

\footnotetext{
* Paper Info: Received: December 16, 2018

Accepted: March 16, 2019

* Corresponding author:

E-mail: yulius@tsm.ac.id; yulius1682@gmail.com

Affiliation: Trisakti School of Management, Indonesia.
} 
Shareholders will assess the company's performance by looking at its income statement, and investors are more interested in buying shares from companies that have a stable income (Parijan, 2013). This fact can contribute to some companies engaging in inappropriate behavior to manipulate profits to improve company performance. Income smoothing is a form of profit manipulation to improve the appearance of company performance. Income smoothing can be detrimental to investors, because investors do not know the real position and financial fluctuations of the company.

This study aims to demonstrate that large companies do not typically engage in income smoothing. Further, companies with high stock prices tend to take income smoothing actions. Mohebi et. al. (2013) states that firm size influences income smoothing. This is contrary to the findings of Ginantra and Putra (2015) which state that firm size does not affect income smoothing. The purpose of the study is to provide empirical evidence that the value of a company increases the likelihood of companies engaging in income smoothing, while large companies tend to reduce income smoothing actions. The study investigates manufacturing companies listed on the Indonesian Stock Exchange.

\section{Literature Review}

\subsection{Agency Theory}

Agency theory is a two-party cooperative relationship, whereby agents carry out their principal's activities. Principals are considered to be only interested in financial returns obtained from their investments in the company, whilst agents are considered to receive satisfaction not only from financial compensation but also from other factors (Godfrey et. al., 2010). In agency theory, accounting information is used for two purposes (Raharjo, 2007). First, it is used for decision making by principals and agents. Second, it is used to evaluate and share the results in accordance with work contracts. This is known as performance evaluation which is used to motivate agents to work more effectively and efficiently.

There are three agency conflicts that give rise to agency costs, which are the costs incurred by shareholders to encourage company managers to maximize the interests of shareholders rather than the interests of the managers themselves (Godfrey et. al., 2010). Agency costs consist of monitoring costs, bonding costs, and residual loss. Monitoring costs are the costs incurred by shareholders to assess, observe, and monitor managerial behavior, for example, audit fees. Bonding costs are costs incurred by the manager as evidence to be considered to have carried out work in accordance in line with the interests of shareholders, for example, the costs incurred in providing financial statements. Residual loss is the cost incurred by shareholders when the manager does not act according to the wishes of the shareholders.

The agent does not always act in accordance with the interests of the principal; management may take actions that do not benefit the company as a whole and which harm the interests of the company. For example, management may use accounting methods to manipulate profits contained in financial statements for their own benefit (Santoso \& Salim, 2012).

Income smoothing is one such management strategy originating from financial reporting (Suryandari, 2012). Income smoothing is usually done in various ways (Harahap, 2011), such as by regulating the timing of a transaction, choosing a principle or method, and regulating the classification between normal operating profit and other profit.

\subsection{Firm Value and Income Smoothing}

The value of a company indicates that prospective investors are willing to pay a certain price when a company is sold. The increasing value of a company indicates the achievement of the company in accordance with the wishes of investors. The company value in this study uses the Price Earnings Ratio (PER). The Price Earnings Ratio is a ratio that measures how investors assess a company's growth in the future by looking at 
the stock price that investors are willing to pay for each reported profit. A high Price Earnings Ratio indicates that the growth rate of a company is also high and vice versa (Prasetyorini, 2013).

If the value of a firm is high, the likelihood of income smoothing is greater, because income smoothing will reduce profit variability and risk of shares (Aji \& Mita, 2010). The company will maintain minimal profit variability so that the company is appealing to investors. Meanwhile, a low company value can be caused by several factors such as low stock price, increasing net profit which reduces the Price Earnings Ratio value, a reduction in stock price etc.

Firm value has an effect on income smoothing caused by higher stock prices which increases firm value. Companies aim for high firm value because this demonstrates the prosperity of the company and is appealing to new and prospective shareholders. Therefore, management are more likely to engage in income smoothing to maintain consistency or stability of profits for each period (Pratiwi \& Handayani, 2014; Peranasari \& Dharmadiaksa, 2014). Further, the value of a company does not influence income smoothing (Gantino, 2015; Noviana \& Yuyetta, 2011). Based on the discussion above, the following hypothesis is proposed:

H1: A higher firm value will increase the likelihood of income smoothing.

\subsection{Firm Size and Income Smoothing}

The size of a company will affect the performance results of the company's management in carrying out their duties (Fiscal \& Steviany, 2015). The larger the size of the company, the more accurate the information given to the market is and the better public access to that information is (Suryandari, 2012).

The size of a company influences the likelihood of income smoothing in companies with large assets. A drastic increase in firm value will pique interest, as this will lead to greater tax liabilities and other things. On the contrary, a drastic decline in profits will give an unfavorable impression and demonstrate that a company is in crisis, which invites government interference. This may contribute to the likelihood of income smoothing in large companies (Noviana \& Yuyetta, 2011).

Firm size has an influence on income smoothing (Mohebi et. al. 2013). Large companies tend to have tighter internal controls compared to smaller companies, because companies with large assets will necessarily attract more attention from the public and the government. This shows that income smoothing in large companies is more common. These results are consistent with Parijan (2013), Peranasari and Dharmadiaksa (2014), Herni and Susanto (2008) and Alexandri (2014).

Meanwhile, Ginantra and Putra (2015) state that company size does not affect earnings, because income smoothing is not influenced by the size of a company, but can be influenced by differences in the desires of each company manager, such as wanting a larger investment, which means that the practice of income smoothing depends on the managers themselves rather than the size of the company. In addition, the influence of company size with income smoothing is caused by investors ignoring the assumption that large companies always have a large amount of assets (Dewantari \& Badera, 2015). Based on the discussion above, the following hypothesis is proposed:

H2: The larger the size of the company, the lower the possibility of income smoothing.

\section{Research Methods}

The population used in this study includes manufacturing companies listed on the Indonesian Stock Exchange between 2014-2016. 51 companies were selected using purposive sampling. Below are the measurements of the variables: 
Table 1. Variable Measurement

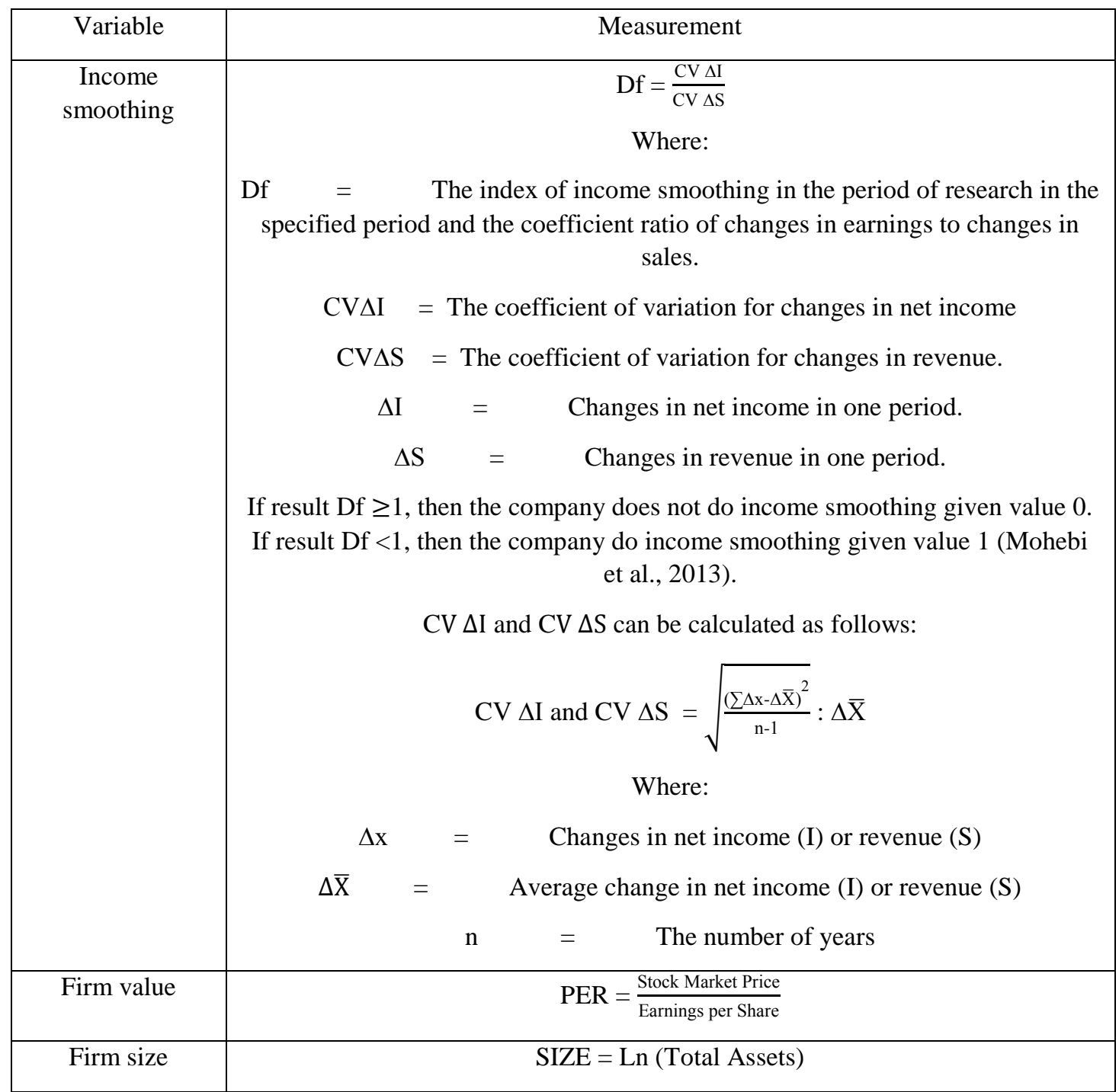

The data analysis tool uses the following binary logistic regression:

$\operatorname{Ln}\left(\frac{P}{1-P}\right)=\alpha+\beta_{1}$ PER $+\beta_{2}$ SIZE $+e$

The first hypothesis is supported if the value of b1 is positive and significant. The second hypothesis is supported if the value of $\mathrm{b} 2$ is negative and significant.

\section{Results}

The results of descriptive statistics and hypothesis testing can be seen in the following table:

Table 2. Descriptive Statistics

\begin{tabular}{|c|c|c|c|c|c|}
\hline Variable & $\mathrm{N}$ & Minimum & Maximum & Mean & Std. deviation \\
\hline Income smoothing & 153 & 0 & 1 & 0,61 & 0,490 \\
\hline
\end{tabular}




\begin{tabular}{|c|c|c|c|c|c|}
\hline Firm value & 153 & 4,2200000 & 299,3300000 & 24,328496732 & 32,3598483702 \\
\hline Firm size & 153 & 25,6194831 & 33,1988120 & 29,280730469 & 1,6580907605 \\
\hline
\end{tabular}

Table 3. Hypothesis Testing

\begin{tabular}{|c|c|c|c|}
\hline Variable & B & Wald & Sig. \\
\hline Constant & 5,759 & 3,453 &, 063 \\
\hline Firm value &, 022 & 3,203 &, $074^{*}$ \\
\hline Firm size &,- 198 & 3,412 &, $065^{*}$ \\
\hline
\end{tabular}

* Sig $10 \%$

Based on the results of the above tests, firm value has a positive effect on income smoothing. Therefore, $\mathrm{H} 1$ is supported. This shows that the higher the stock price, the higher the likelihood that the company will engage in income smoothing. An increase in stock price demonstrates a company's ability to fulfill investors' wishes. The company is considered good by investors so that income smoothing is efficient. These results are consistent with research by Pratiwi and Handayani (2014), Peranasari and Dharmadiaksa (2014) and Aji and Mita (2010). A high value of a company can allow management to freely carry out income smoothing actions, because shareholders considers the actions of management to always be in accordance with the interests of shareholders.

Testing for company size shows that firm size has a negative effect on income smoothing. Therefore, $\mathrm{H} 2$ is supported. This shows that the larger the company, the lower the possibility of income smoothing. Large companies are a concern for all stakeholders. Large companies are established by stakeholders and the possibility of companies to carry out opportunistic income smoothing actions is lower. These results are consistent with research by Parijan (2013), Peranasari and Dharmadiaksa (2014), Herni and Susanto (2008) and Alexandri (2014). Large companies receive more public attention and monitoring by external parties. This makes it more difficult for management to carry out income smoothing actions.

\section{Conclusion}

Based on the results of this study, it can be concluded that firm value has a positive effect on income smoothing, whilst firm size has a negative effect on income smoothing. When management succeeds in fulfilling the wishes of investors, investors assume that the actions of management are correct. Further, large companies are the center of attention for stakeholders, so the possibility of income smoothing is reduced. This study also shows that agency costs in the form of firm size can minimize opportunist income smoothing actions.

This study has some limitations that may affect the results of the study, namely:

1. This study only examines a three year period, namely between 2014 and 2016 .

2. Only two independent variables are used.

3. This study uses the Eckel index to measure income smoothing, without regard to other measurement methods.

Recommendations for further research include:

1. The addition or extension of the time of the research to better explain the relationship between the independent variables and their effect on income smoothing. 
2. The addition of further independent variables that affect income smoothing such as public ownership, company growth and taxes listed on the Indonesian Stock Exchange.

3. The use of different approaches to measure income smoothing in addition to the Eckel index, such as the ratio of firm J's standard deviation of net income divided standard deviation of cash flows from operations (Francis et. al., 2004).

\section{References}

Aji, Yudho Dhamar and Mita, Aria Farah. (2010). The Effect of Profitability, Financial Risk, Corporate Value and Ownership Structure on Profit Smoothing Practices: An Empirical Study of Manufacturing Companies Listed on the IDX. Simposium Nasional Akuntansi XIII Purwokerto.

Alexandri, Benny Moh. (2014). Income Smoothing: Impact Factors, Evidence in Indonesia. International Journal of Small Business and Entrepreneurship Research, 3(1), 21-27.

Beattie, Vivien, Stephen Brown, David Ewers, Brian John, Stuart Manson, Dylan Thomas and Michael Turner. (1994). Extraordinary Items and Income Smoothing: A Positive Accounting Approach. Journal of Business Finance and Accounting, 21(6), pp. 791-811.

Dewantari, Ni Putu Santi and Badera, I Dewa Nyoman. (2015). Good Corporate Governance, Company Size, and Financial Leverage as Predictors of Income Smoothing. E-Journal Akuntansi Universitas Udayana, 10(2), pp. 538-553.

Fiscal, Yunus and Steviany, Agatha. (2015). The Effect of Size Company, Profitability, Financial Leverage and Dividend Payout Ratio on Income Smoothing In The Manufacturing Companies Listed In Indonesia Stock Exchange. Journal Akuntansi dan Keuangan, 6(2), pp. 11-24.

Francis, J., Olsson, P. and Schipper, K. (2004). Costs of Equity and Earnings Attributes. The Accounting Review, 79, pp. 967-1010.

Gantino, Rilla. (2015). Effect of Managerial Ownership Structure, Financial Risk and Its Value on Income Smoothing in the Automotive Industry and Food and Beverage Industry Listed in Indonesia Stock Exchange. Research Journal of Finance and Accounting, 6(4), pp. 48-55.

Ginantra, I Komang Gede and Putra, I Nyoman Wijana Asmara. (2015). The Effect of Profitability, Leverage, Company Size, Public Ownership, Dividend Payout Ratio and Net Profit Margin on Income Smoothing. E-Journal Akuntansi Unversitas Udayana, 10(2), pp. 517-602.

Godfrey, Jayne, Allan Hogson, Scott Holmes and Ann Tarca. (2010). Accounting Theory. Sixth Edition. Australia: John Wiley \& Sons Australia Ltd.

Harahap, Sofyan Syafri. (2011). Accounting Theory, 2011 Revised Edition Jakarta: Rajawali Press.

Herni and Susanto, Yulius Kurnia. (2008). The Effect of Public Ownership Structures, Corporate Management Practices, Industrial Types, Firm Size, Profitability and Financial Risk against Profit Smoothing Measures (Empirical Study in Industries with Listings on the Jakarta Stock Exchange). Journal Ekonomi dan Bisnis Indonesia, 23(3).

Mohebi, Fatemeh, Mohammad Mahmoodi and Naser Ail Yadollahzadeh. (2013). The Investigation of the Effect of Firm-Specific Accounting Variables on Income Smoothing of Companies: Evidence from Tehran Stock Exchange. World of Sciences Journal, 1(11), pp. 109-116.

Noviana, Sindi Retno and Yuyetta, Etna Nur Afri. (2011). Analysis of Factors Affecting the Practice of Profit Smoothing (Empirical Study of Manufacturing Companies Listed on the Indonesia Stock Exchange 2006-2010). Journal Akuntansi and Auditing, 8(1), pp. 1-94.

Parijan, Khadijeh Khodabakhshi. (2013). Income Smoothing Practice: An Empirical Investigation of Listed Firms in Tehran Stock Exchange. Indian Streams Research Journal, 3(5), pp. 1-5.

Peranasari, Ida Ayu Agung Istri and Dharmadiaksa, Ida Bagus. (2014). Income Smoothing Behaviour, and the Affecting Factors. E-Journal Akuntansi Universitas Udayana, 8(1), pp. 140-153.

Prasetyorini, Bhekti Fitri. (2013). The Effect of Company Size, Leverage, Price Earnings Ratio and Profitability on Company Values. Journal Ilmu Manajemen, 1(1), pp. 183-196.

Pratiwi, Herlinda and Handayani, Bestari Dwi, (2014). The Effect of Profitability, Managerial Ownership and Taxes on Profit Levelling Practices. Accounting Analysis Journal, 3(4), pp. 264-272.

Raharjo, Eko. (2007). Agency Theory and Stewardship Theory in the Accounting Perspective. Fokus Ekonomi, 2(1), pp. 37-46. 
Santoso, Eko Budi \& Salim, Sherly Novia. (2012). The Effect of Profitability, Financial Leverage, Dividends, Company Size, Institutional Ownership, and Business Groups Against Profit Smoothing Case Study on Non-Financial Companies Against the IDX. Proceedings of Conference in Business, Accounting and Management, 1(1), 185-200.

Suryandari, Ni Nyoman Ayu. (2012). Analysis of Factors Affecting Income Smoothing. Media Komunikasi, 11(1), 115. 